\title{
Carbon Dioxide Uptake in Demolished and Crushed Concrete
}

\author{
Toshifumi Kikuchi ${ }^{1}$ and Yasuhiro Kuroda ${ }^{2}$
}

Received 18 May 2010, accepted 19 December 2010

\begin{abstract}
One of the largest contributors of the greenhouse gas emission is the production of cement for use in concrete. However, concrete is well-known for its carbon dioxide $\left(\mathrm{CO}_{2}\right)$ uptake by carbonation. The purpose of this study was to consider the $\mathrm{CO}_{2}$ uptake in demolished and crushed concrete. In this study, three kinds of experiments and survey were carried out, including (1) an experiment using mortar specimens made in the laboratory so as to identify the conditions that accelerate $\mathrm{CO}_{2}$ uptake, (2) an experiment using concrete obtained from the demolition site and (3) a survey on the $\mathrm{CO}_{2}$ uptake in recycled crusher-run stone obtained from recycling plants. The experiment on new mortar and demolished concrete pointed out that the $\mathrm{CO}_{2}$ uptake in cement hydrate increases significantly when the particles are relatively small and when they are alternately wetted and dried. Furthermore, the survey on concrete at recycling plants found the amount of $\mathrm{CO}_{2}$ uptake in one ton of recycled crusher-run stone to be approximately 11 kilograms. Finally, using this value, the life cycle of $\mathrm{CO}_{2}$ of concrete structures was calculated and shown to be approximately $5.5 \%$ less when the $\mathrm{CO}_{2}$ uptake is taken into account compared to when it is not taken into account.
\end{abstract}

\section{Introduction}

\subsection{Background}

The production of Portland cement, an essential constituent of concrete, leads to the release of significant amounts of carbon dioxide $\left(\mathrm{CO}_{2}\right)$, a greenhouse gas. It is said that the production of one ton of Portland cement clinker creates approximately one ton of $\mathrm{CO}_{2}$ (Naik and Moriconi 2005). Approximately half of the $\mathrm{CO}_{2}$ emissions from cement production stem from the calcination of limestone, i.e. the process where limestone is burnt and $\mathrm{CO}_{2}$ gas is released to the atmosphere. Theoretically, hardened concrete binds approximately the same account of $\mathrm{CO}_{2}$ in a carbonation process (Engelsen et al. 2005).

Carbonation of concrete is a well-known process, where cement hydrates of concrete react with atmospheric $\mathrm{CO}_{2}$ to form calcium carbonate $\left(\mathrm{CaCO}_{3}\right)$. It is a process that occurs from the surface of the concrete and the amount of carbonated concrete is related to exposure time as well as surface area. When concrete structures are demolished and crushed, the surface area per unit weight of concrete increases significantly. Therefore, the $\mathrm{CO}_{2}$ uptake rate per unit mass of concrete and thus the total amount of $\mathrm{CO}_{2}$ uptake increase after the demolishing stage.

Recently, there have been many research studies on the $\mathrm{CO}_{2}$ uptake of concrete. In Northern Europe, the $\mathrm{CO}_{2}$ emission as well as the $\mathrm{CO}_{2}$ uptake during the life

\footnotetext{
${ }^{1}$ Research Engineer, Institute of Technology, Shimizu Corporation, Tokyo, Japan.

E-mail: t_kikuchi@shimz.co.jp

2 Senior Research Engineer, Institute of Technology, Shimizu Corporation, Tokyo, Japan.
}

cycle of concrete have been considered in the assessment of the life cycle $\mathrm{CO}_{2}\left(\mathrm{LCCO}_{2}\right)$ of reinforced concrete structures (e.g. Lagerblad 2005; Pommer and Pade 2005; Nielsen and Glavind 2007). In a project called " $\mathrm{CO}_{2}$ uptake during the concrete life cycle" of the Nordic Innovation Center (e.g. Lagerblad 2005), the carbonation rates of different types of concrete under various conditions, including the rate of carbonation during secondary life, i.e. after demolition and crushing of the concrete, have been assessed. That project also estimated the annual production of various concrete types and products. "Guidelines - Uptake of carbon dioxide in the life cycle inventory of concrete" (Pommer and Pade 2005) represents, based on the findings of the project, an attempt to establish a general procedure of $\mathrm{CO}_{2}$ life cycle inventory that adequately includes all phases in the life and secondary life of any concrete product.

The above-mentioned research studies were marked by the acceptance of many assumptions and a lack of experimental data. Disposing of more quantitative information based on experiments and surveys on the carbonation of actual concrete in structures before demolition work and also in recycling plant would go a long way toward overcoming these shortcomings.

\subsection{Research objectives}

As mentioned earlier, there is a lack of quantitative information about the carbonation of demolished and crushed concrete. Therefore, the objectives of this research were to quantify the amount of $\mathrm{CO}_{2}$ uptake in demolished and crushed concrete, to identify the conditions that promote $\mathrm{CO}_{2}$ uptake, and clarify the influence of $\mathrm{CO}_{2}$ uptake on the $\mathrm{LCCO}_{2}$ in reinforced concrete structures. 


\begin{tabular}{|c|c|c|}
\hline Material process & $\mathrm{CO}_{2}$ emission & $\mathrm{CO}_{2}$ emission \\
\hline Cement & $22965 \mathrm{~kg}$ & $38636 \mathrm{~kg}$ \\
\hline S and & $276 \mathrm{~kg}$ & \multirow[b]{4}{*}{$\mathrm{CO}_{2}$ emission } \\
\hline Gravel & $289 \mathrm{~kg}$ & \\
\hline Reinforced Bar & $15106 \mathrm{~kg}$ & \\
\hline Concrete and construction process & $\mathrm{CO}_{2}$ emission & \\
\hline Concrete plant & $1778 \mathrm{~kg}$ & $2251 \mathrm{~kg}$ \\
\hline Equipment & $185 \mathrm{~kg}$ & \multirow{3}{*}{ Use anc } \\
\hline Heavy machinery & $159 \mathrm{~kg}$ & \\
\hline Vehicle & $129 \mathrm{~kg}$ & \\
\hline Demolition process & $\mathrm{CO}_{2}$ emission & $\mathrm{CO}_{2}$ emission \\
\hline Equipment & $74 \mathrm{~kg}$ & $2427 \mathrm{~kg}$ \\
\hline Heavy machinery & $2353 \mathrm{~kg}$ & \\
\hline Recycling process & $\mathrm{CO}_{2}$ emission & $\mathrm{CO}_{2}$ emission \\
\hline Equipment & $211 \mathrm{~kg}$ & $440 \mathrm{~kg}$ \\
\hline Heavy machinery & $229 \mathrm{~kg}$ & \\
\hline Transport process & $\mathrm{CO}_{2}$ emission & $\mathrm{CO}_{2}$ emission \\
\hline Vehicle & $1647 \mathrm{~kg}$ & $1647 \mathrm{~kg}$ \\
\hline & & $\mathrm{LCCO}_{2}$ emission \\
\hline & & $45403 \mathrm{~kg}$ \\
\hline
\end{tabular}

Fig. $1 \mathrm{LCCO}_{2}$ calculation.

\subsection{Method of calculation of $\mathrm{LCCO}_{2}$}

In the calculation of $\mathrm{LCCO}_{2}$, the inventory analysis includes the following processes: material, concrete production and construction, demolition, recycling, and transport. First, the amount of $\mathrm{CO}_{2}$ emission during each process was calculated and summed up. The amounts of $\mathrm{CO}_{2}$ emission during the material, concrete and construction, demolition, and transport processes were actually quoted from data listed in Japan Society of Civil Engineers (2004, p.32-40). On the other hand, for the calculation of the $\mathrm{CO}_{2}$ emission during the recycling process, it was assumed that the recycling plants are relatively small. Therefore, the crushing capacity and operating capacity of the recycling plants that produced the recycled crusher-run stone ( 0 to 40 millimeters) were assumed to be 100 tons per hour and $80 \%$, respectively. In addition, the amount of $\mathrm{CO}_{2}$ uptake in one ton of recycled crusher-run stone can be calculated using the following equation:

$$
x=a \times(1-b) \times c \times d(\mathrm{~kg})
$$

where,

$x$ : amount of $\mathrm{CO}_{2}$ uptake by one ton of recycled crusher-run stone $(\mathrm{kg})$,

$a$ : ratio of particle less than or equal to 5 millimeters,

$b$ : ratio of insoluble residue,

c: $\mathrm{CaCO}_{3}$ content,

$d$ : ratio of molecular weights of $\mathrm{CO}_{2}$ and $\mathrm{CaCO}_{3}$.

The molecular weights used in the calculation are as follows:

$$
\mathrm{CaCO}_{3}=100.1, \mathrm{CO}_{2}=44.0
$$

Using the results of the insoluble residue test and the thermogravimetry - differential thermal analysis (TG-DTA) test for test materials of several particle sizes, the amount of $\mathrm{CO}_{2}$ uptake was calculated by setting values for the " $a$ " to " $c$ " variables of equation (1) above.

For example, assuming the volume of reinforced concrete to be 100 cubic meters, the inventory analysis of the materials and their $\mathrm{LCCO}_{2}$ values can be calculated as shown in Fig. 1. The unit contents and the amount of materials used are shown in Table 1. In this example, the water to cement ratio was $55 \%$, and the sand content was $44 \%$.

\begin{tabular}{|c|c|c|c|}
\hline & $\begin{array}{l}\text { Unit quantity } \\
\left(\mathrm{kg} / \mathrm{m}^{3}\right)\end{array}$ & $\begin{array}{c}\text { Amount used } \\
\left(\text { ton } / 100 \mathrm{~m}^{3}\right)\end{array}$ \\
\hline \multirow{5}{*}{ Material } & Water & 165 & 16.5 \\
\hline & Cement (OPC) & 300 & 30 \\
\hline & Sand & 800 & 80 \\
\hline & Gravel & 1050 & 105 \\
\hline & Reinforcement & - & 20 \\
\hline
\end{tabular}

Table 1 Mixing proportion and materials. 


\section{Experiments and survey}

In this study, three kinds of experiments and survey were carried out, including (1) an experiment on mortar cast and cured in the laboratory so as to identify the conditions (water to cement ratio, types of cements, particle size and exposure conditions) that accelerate the $\mathrm{CO}_{2}$ uptake, (2) an experiment on concrete obtained from the building demolition site and (3) a survey on the $\mathrm{CO}_{2}$ uptake in the recycled crusher-run obtained from recycling plants, focusing on the crusher-run in the size range of 0 to 40 millimeters. Details of the experiments and plant survey are reported below.

\subsection{Experiment on new mortar (1) Preparation of mortar specimens and test materials}

Ordinary Portland cement (OPC) and B-class Portland blast-furnace slag cement $(\mathrm{BB})$ were used in the mortar experiments (Table 2). Silica sand was used as fine aggregate, and ion-exchange water was used for mixing. The water to cement ratio was either 0.6 or 0.4 , and the sand to cement ratio was 3.0 in all mixtures. The mortar was mixed using a Hobart mixer and cast into plastic molds. Afterwards, the mortar specimens were seal-cured and kept at a constant room temperature (20 degrees Celsius) for a year. Subsequently, each mortar specimen was crushed to a size not larger than 5 millimeters using a jaw crusher.

The test material (i.e., crushed mortar) was placed in a standard curing room where the temperature and relative humidity were maintained constant at 20 degrees Celsius and $65 \%$ relative humidity, respectively. In this room, two exposure conditions including dried (D) and alternately wetted and dried (WD) were applied in different periods of 0,28 and 91days.

The examination and adjustment of the moisture condition of crushed mortar are shown in Fig. 2. The alternately wetted and dried crushed mortar was thoroughly mixed and sprayed with water twice a week (as the number of rainy days is statistically 100 days per year in Tokyo) in such a way that the resultant moisture content was about $15 \%$, which approximates the actual environment. This includes consideration of the fact that when buildings are demolished, water is usually sprinkled for dust suppression. Besides, in actual situations, the demolished concrete at the sites or recycling plants are usually stored in open space and usually mixed up
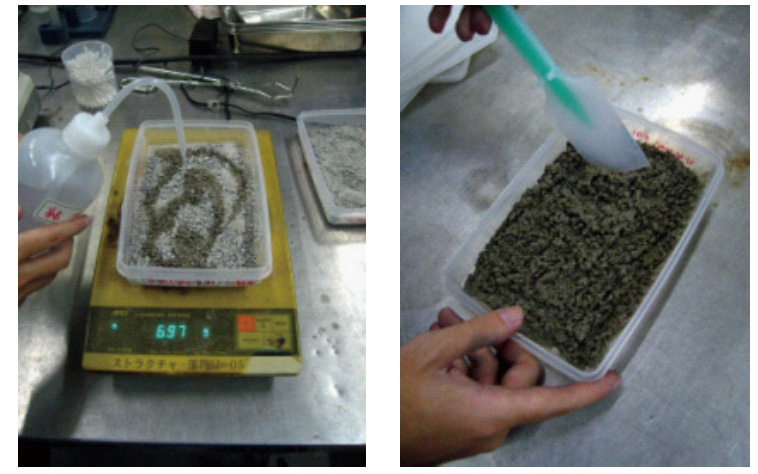

Fig. 2 Examination and adjustment of moisture condition.

during transportation. It has been reported in Kuroda and Hashida (2005, p. 667-683) that the average moisture content of recycled crusher-run stone at the site is around $11 \%$ with standard variation of $1.9 \%$. Meanwhile, the dried test materials were also thoroughly mixed twice a week to achieve homogeneity in the moisture condition.

After being exposed for the required period of time (up to 91 days), the test materials were soaked in an acetone solution, mixed for 20 minutes, and then soaked in new acetone again for over 12 hours for dehydration. They were then vacuum-dried for around 24 hours before being screened into three groups of test materials with three particle size ranges of 0 to 0.5 millimeters, 0.5 to 2 millimeters, and 2 to 5 millimeters. Furthermore, each group of test material was additionally crushed using a disk mill until their particle size reached 0.15 millimeters or less.

\section{(2) Test methods}

Two kinds of tests including the insoluble residue test (Standard test method JCAS F-18 of Japan Cement Association) and the TG-DTA test were conducted. The insoluble residue test was carried out by dissolving the test materials in hydrochloric acid in order to determine the amount of insoluble residue that is required for calculation of the aggregate content. This test was carried out just once, except in the case in which the test material was made with ordinary Portland cement, water to cement ratio of 0.6 , and exposed under dried condition. This exceptional case was tested 3 times, and the standard variation of the obtained result was as small as 0.06 to $0.25 \%$.

Table 2 Properties of cement used in tests on new mortar.

\begin{tabular}{|c|c|c|c|c|c|c|c|c|c|c|c|c|c|}
\hline \multirow{2}{*}{ Cement } & \multirow{2}{*}{$\begin{array}{c}\text { Specific } \\
\text { gravity } \\
\mathrm{g} / \mathrm{cm}^{3}\end{array}$} & \multirow{2}{*}{$\begin{array}{c}\text { Specific } \\
\text { surface area } \\
\mathrm{cm}^{2} / \mathrm{g}\end{array}$} & \multicolumn{11}{|c|}{ Chemical composition \% } \\
\hline & & & lg.loss & insol. & $\mathrm{SiO}_{2}$ & $\mathrm{Al}_{2} \mathrm{O}_{3}$ & $\mathrm{Fe}_{2} \mathrm{O}_{3}$ & $\mathrm{CaO}$ & $\mathrm{MgO}$ & $\mathrm{SO}_{3}$ & $\mathrm{Na}_{2} \mathrm{O}$ & $\mathrm{K}_{2} \mathrm{O}$ & $\mathrm{Cl}$ \\
\hline OPC & 3.16 & 3250 & 2.13 & 0.12 & 20.49 & 5.75 & 3.11 & 64.12 & 0.97 & 1.89 & 0.20 & 0.44 & 0.01 \\
\hline BB & 3.04 & 3830 & 2.83 & 0.17 & 24.72 & 8.86 & 1.86 & 55.08 & 2.80 & 2.38 & 0.27 & 0.35 & 0.01 \\
\hline
\end{tabular}


The TG-DTA test was carried out in order to determine the contents of calcium hydrate $\left(\mathrm{Ca}(\mathrm{OH})_{2}\right)$ and calcium carbonate $\left(\mathrm{CaCO}_{3}\right)$ in the test materials. This test was carried out just once except in the case in which test material was made with ordinary Portland cement, water to cement ratio of 0.6 , particle size range of 0.5 to 2 millimeters, and exposed under dried condition for a period of 91 days. This exceptional case was tested 3 times and the standard deviations of the obtained amounts of $\mathrm{Ca}(\mathrm{OH})_{2}$ and $\mathrm{CaCO}_{3}$ contents were as small as $2.2 \%$ and $1.2 \%$, respectively.

In the TG-DTA test, the temperature was increased at the rate of 10 degrees Celsius per minute from room temperature to 1000 degrees Celsius. The endothermic peak from about 450 to 500 degrees Celsius during DTA was regarded to be due to the dehydration of $\mathrm{Ca}(\mathrm{OH})_{2}$ and that at about 600 to 750 degrees Celsius was regarded to be due to the decarboxylation of $\mathrm{CaCO}_{3}$. Here, the $\mathrm{Ca}(\mathrm{OH})_{2}$ and $\mathrm{CaCO}_{3}$ contents of the mortar were calculated from the mass loss during $\mathrm{TG}$ analysis. In fact, the $\mathrm{Ca}(\mathrm{OH})_{2}$ content of the mortar was calculated from the mass loss during TG analysis in relation to the DTA curve from the start point of temperature to the end point in the temperature range of 450 to 500 degrees Celsius. Meanwhile, the $\mathrm{CaCO}_{3}$ content of the mortar was calculated by the mass loss during TG analysis in relation to the DTA curve from the start point (600 degrees Celsius) of temperature to the end point in the temperature range about 600 to 800 degrees Celsius. Using these results, the unit contents of $\mathrm{Ca}(\mathrm{OH})_{2}$ and $\mathrm{CaCO}_{3}$ in cement paste were calculated. In these calculations, the molecular weights used in the calculation are as follows: 44.0

$$
\mathrm{Ca}(\mathrm{OH})_{2}=74.1, \mathrm{CaCO}_{3}=100.1, \mathrm{H}_{2} \mathrm{O}=18.0, \mathrm{CO}_{2}=
$$

\subsection{Experiment on demolished concrete \\ (1) Concrete specimens}

The demolished concrete was obtained from the demolition of a building constructed in 1963 in Tokyo. The average core strength of the original concrete was 26.7 newtons per square millimeter. The demolished concrete was kept in a bag for about three months (Fig. 3) before being crushed to a size of less than 150 millimeters using a chisel. Subsequently, all the concrete pieces were crushed to a size not larger than 10 millimeters by using a jaw crusher. The crushed concrete materials ( 0 to 10 millimeters) were then placed under two exposure conditions (D and WD), similar to those of the crushed mortar (see Section 2.1). The adjustment of moisture content of the test material under wetted and dried condition was carried out by spraying water once a week. The exposure periods were also 0, 28, and 91 days.

Similarly, after the exposure period, the test materials were dehydrated by acetone before being screened into two groups with the particle size ranges of 0 to 2 millimeters, and 0 to 10 millimeters. The test materials were also further crushed using a disk mill until the particles reached a size not larger than 0.15 millimeters.

\section{(2) Test methods}

Similar to the experiment on new mortar, an insoluble residue test and TG-DTA test were conducted, and the insoluble residue, the contents of $\mathrm{Ca}(\mathrm{OH})_{2}$ and $\mathrm{CaCO}_{3}$, was measured.

\subsection{Field survey on recycling plant (1) Recycling plants}

An external view of one of the recycling plants is shown in Fig. 4 and an example of the recycled crusher-run is shown in Fig. 5. In Japan, the recycling ratio of demolished concrete is estimated to be more than $98 \%$ (Noguchi and Fujimoto 2007), and most recycling plants produce 0 to 40 millimeters recycled crusher-run stone for use as roadbed material.

\section{(2) Survey and test methods}

Eight typical recycling plants around the Tokyo metropolitan area were surveyed in this study. The method of survey was oral interviews on the methods of crushing and storage of demolished concrete, etc. Meanwhile, three kinds of tests including the screening tests, the

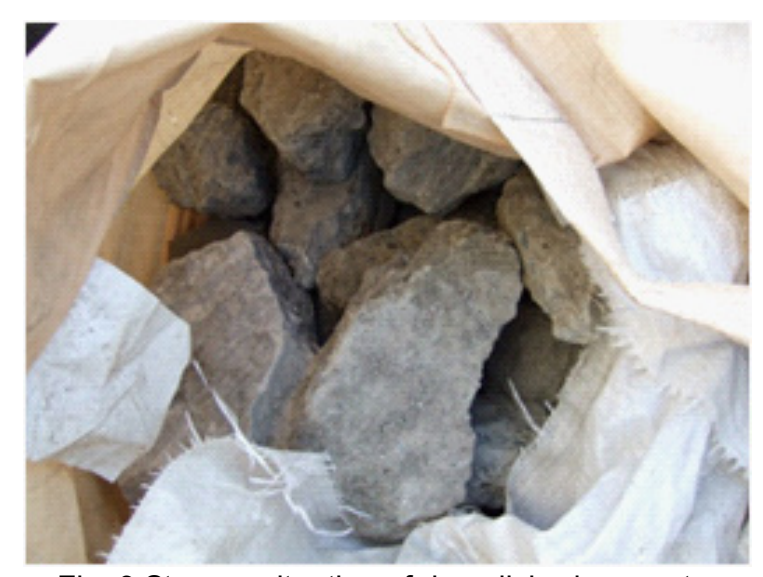

Fig. 3 Storage situation of demolished concrete.

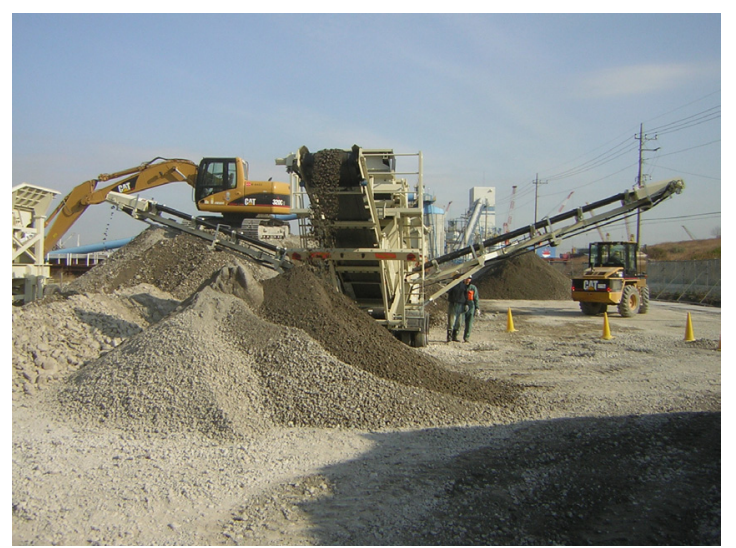

Fig. 4 External view of a recycling plant of Tokyo. 


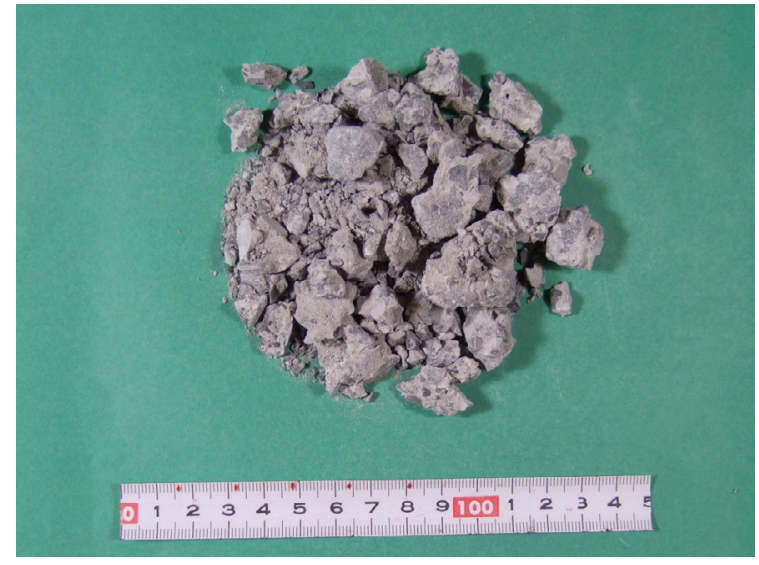

Fig. 5 Example of recycled crusher-run stone.

insoluble residue test and the TG-DTA test were conducted on the recycled crusher-run stone from these plants. The screening test of the recycle concrete was carried out using screen sizes of $40,20,5,2$, and 0.5 millimeters so as to identify the amount of small particles, which have a greater $\mathrm{CO}_{2}$ uptake effect than large particles.

Similar to the experiments on new mortar and demolished concrete, the test materials were carefully prepared for the insoluble residue and TG-DTA tests. However, these two tests were carried out just on the particles not larger than 5 millimeters (selected by screening), because the carbonation rate was considered to be much lower and the aggregate ratio larger for particles greater than 5 millimeters, compared with parti- cles smaller than 5 millimeters. Therefore, taking into account only particles smaller than 5 millimeters is believed to result in more accurate overall estimation compared with when all particles sizes are considered.

\section{Results of experiment and survey}

\subsection{Results of experiment on new mortar}

The results of the experiment on new mortar are listed in Table 3, and the content of $\mathrm{CaCO}_{3}$ in the cement paste of the mortars of different sizes is shown in Fig. 6. Regarding the effect of the water to cement ratio, the $\mathrm{CaCO}_{3}$ content of the mortar with water to cement ratio of 0.6 was higher than that in the mortar with water to cement ratio of 0.4 . This is believed to be due to the fact that the hydration product of the mortar with high water to cement ratio is more porous, resulted in a higher carbonation rate. Regarding the effect of cement type, the $\mathrm{CaCO}_{3}$ content in the case of OPC use was found to be higher than in the case of $\mathrm{BB}$ cement use, possibly due to the fact that the $\mathrm{Ca}(\mathrm{OH})_{2}$ content in concrete using $\mathrm{BB}$ cement is smaller than in the case of concrete using OPC. As for the influence of particle size, it was found that the smaller the particle size, the faster the carbonation rate was, even in the case of low water to cement ratio. This is because of the larger surface area (in contact with the atmosphere) per unit mass of small particles compared to that of larger particles. Regarding the effect of the exposing condition, it was confirmed that the carbonation rate of specimens in the alternately wetted and dried condition was higher than that of specimens in the dried condition.

Table 3 Results of experiment on new mortar.

\begin{tabular}{|c|c|c|c|c|c|c|c|c|c|c|c|c|}
\hline \multirow{2}{*}{$\begin{array}{l}\text { Type of } \\
\text { cement }\end{array}$} & \multirow[b]{2}{*}{$\mathrm{W} / \mathrm{C}$} & \multirow{2}{*}{$\begin{array}{l}\text { Exposed } \\
\text { condition }\end{array}$} & \multirow{2}{*}{$\begin{array}{c}\text { Particle } \\
\text { sizes } \\
\text { mm }\end{array}$} & \multicolumn{3}{|c|}{0 days } & \multicolumn{3}{|c|}{28 days } & \multicolumn{3}{|c|}{91 days } \\
\hline & & & & $\begin{array}{c}\text { insol. } \\
\%\end{array}$ & $\begin{array}{c}\mathrm{Ca}(\mathrm{OH})_{2} \\
\%\end{array}$ & $\begin{array}{c}\mathrm{CaCO}_{3} \\
\%\end{array}$ & $\begin{array}{c}\text { insol. } \\
\%\end{array}$ & $\begin{array}{c}\mathrm{Ca}(\mathrm{OH})_{2} \\
\%\end{array}$ & $\begin{array}{c}\mathrm{CaCO}_{3} \\
\%\end{array}$ & $\begin{array}{c}\text { insol. } \\
\%\end{array}$ & $\begin{array}{c}\mathrm{Ca}(\mathrm{OH})_{2} \\
\%\end{array}$ & $\begin{array}{c}\mathrm{CaCO}_{3} \\
\%\end{array}$ \\
\hline \multirow{6}{*}{ OPC } & \multirow{6}{*}{0.40} & \multirow{3}{*}{$\mathrm{D}$} & $0.5-0$ & \multirow{6}{*}{68.4} & \multirow{6}{*}{10.8} & \multirow{6}{*}{2.0} & 58.9 & 11.5 & 9.4 & 61.8 & 7.4 & 17.3 \\
\hline & & & $2-0.5$ & & & & 73.3 & 9.3 & 3.1 & 77.5 & 9.0 & 10.5 \\
\hline & & & $5-2$ & & & & 69.5 & 12.4 & 3.0 & 70.5 & 11.2 & 8.4 \\
\hline & & \multirow{3}{*}{ WD } & $0.5-0$ & & & & 61.7 & - & 53.6 & 64.0 & - & 67.7 \\
\hline & & & $2-0.5$ & & & & 60.6 & - & 17.2 & 76.0 & 3.1 & 30.0 \\
\hline & & & $5-2$ & & & & 66.2 & 6.8 & 8.8 & 68.5 & 6.9 & 14.2 \\
\hline \multirow{6}{*}{$\mathrm{OPC}$} & \multirow{6}{*}{0.60} & \multirow{3}{*}{$\mathrm{D}$} & $0.5-0$ & \multirow{6}{*}{68.3} & \multirow{6}{*}{12.6} & \multirow{6}{*}{2.2} & 57.2 & 11.5 & 19.2 & 58.4 & 8.0 & 32.9 \\
\hline & & & $2-0.5$ & & & & 79.7 & 12.2 & 6.8 & 79.5 & - & 26.2 \\
\hline & & & $5-2$ & & & & 70.3 & 14.8 & 3.8 & 70.5 & 7.5 & 32.1 \\
\hline & & \multirow{3}{*}{ WD } & $0.5-0$ & & & & 54.0 & - & 55.4 & 57.5 & - & 66.0 \\
\hline & & & $2-0.5$ & & & & 72.6 & - & 34.0 & 73.2 & - & 33.7 \\
\hline & & & $5-2$ & & & & 69.4 & 5.9 & 17.0 & 68.2 & 5.3 & 25.3 \\
\hline \multirow{6}{*}{ BB } & \multirow{6}{*}{0.60} & \multirow{3}{*}{$\mathrm{D}$} & $0.5-0$ & \multirow{6}{*}{69.6} & \multirow{6}{*}{7.7} & \multirow{6}{*}{0.9} & 56.2 & 6.2 & 9.1 & 58.0 & - & 22.4 \\
\hline & & & $2-0.5$ & & & & 74.2 & 4.8 & 5.6 & 77.5 & - & 17.4 \\
\hline & & & $5-2$ & & & & 68.8 & 4.4 & 5.5 & 69.5 & - & 13.7 \\
\hline & & \multirow{3}{*}{ WD } & $0.5-0$ & & & & 54.9 & - & 45.2 & 57.6 & - & 51.0 \\
\hline & & & $2-0.5$ & & & & 71.5 & 1.0 & 18.2 & 72.1 & - & 29.4 \\
\hline & & & $5-2$ & & & & 71.0 & 3.0 & 10.7 & 69.3 & 2.8 & 15.6 \\
\hline
\end{tabular}

\footnotetext{
"-" means that the endothermic peak was indeterminable.
} 
The $\mathrm{Ca}(\mathrm{OH})_{2}$ content of specimens in the alternately wetted and dried condition, which had small-sized particles, decreased significantly while the $\mathrm{CaCO}_{3}$ content increased significantly. It was speculated that the $\mathrm{Ca}(\mathrm{OH})_{2}$ consumption of specimens in the alternately wetted and dried condition was accelerated because the $\mathrm{Ca}(\mathrm{OH})_{2}$ eluted from the solid phase. For example, Na-

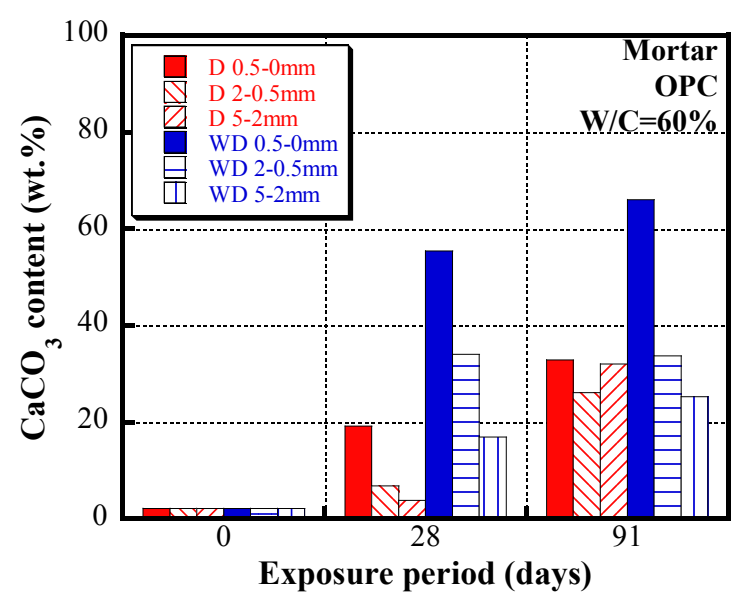

(a) W/C: 60\%, Cement: OPC

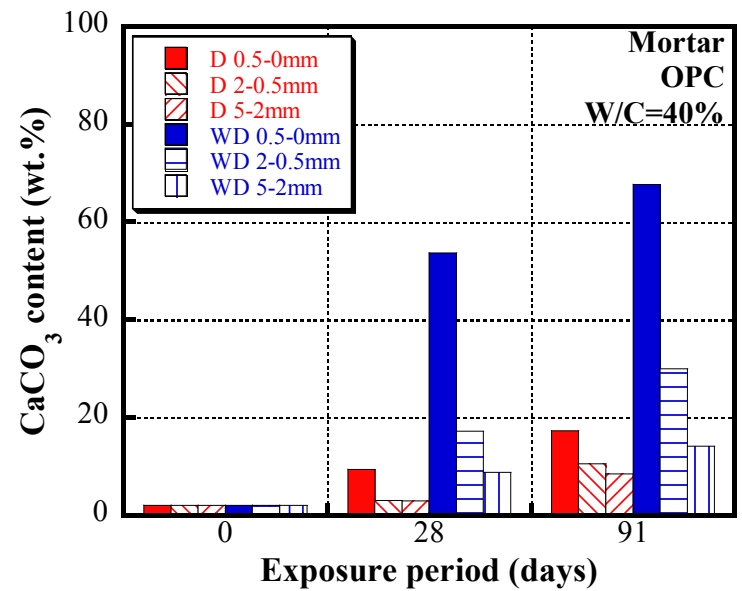

(b) W/C: $40 \%$, Cement: OPC

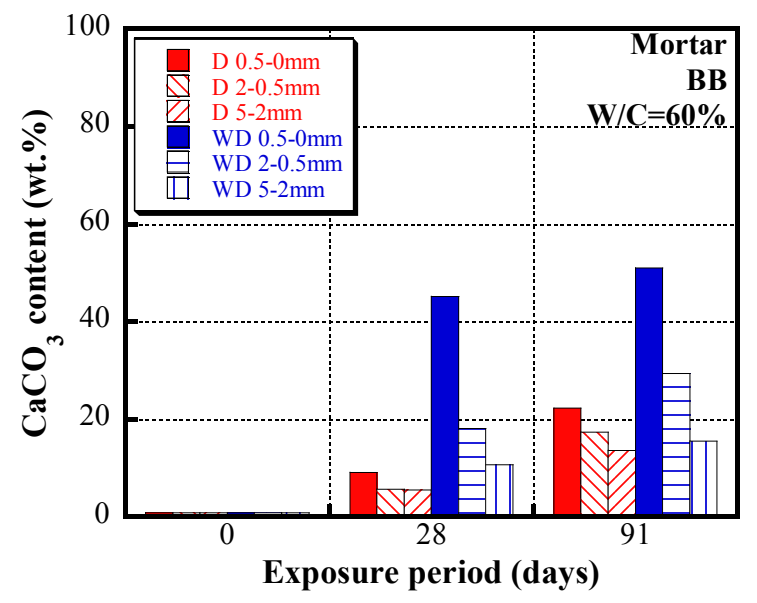

(c) W/C: $60 \%$, Cement: BB

Fig. $6 \mathrm{CaCO}_{3}$ content in cement paste of mortar specimens. kamura (1994, p.584-589) have demonstrated that the carbonation rate increases with the water-mediated effect. Further, despite the fact that all of the $\mathrm{Ca}(\mathrm{OH})_{2}$ contents in specimens has been consumed, the $\mathrm{CaCO}_{3}$ content will continue to increase, because not only $\mathrm{Ca}(\mathrm{OH})_{2}$ but also other cement hydrates (i.e. calcium silicate hydroxide and calcium aluminate hydroxide) have been carbonated.

\subsection{Results of experiment on demolished con- crete}

The results of the experiment are listed in Table 4, and the relation between the exposure period and the $\mathrm{CaCO}_{3}$ content ratio is shown in Fig. 7. It can be seen in this figure that the $\mathrm{CaCO}_{3}$ content had already exceeded $10 \%$ at the beginning of exposure. This is believed to be due to the carbonation during the in-service and post-demolition storage periods. However, the storage period after demolition might be much more dominant than the in-service period because of the small particle size or, more exactly, the larger surface area in contact with atmospheric $\mathrm{CO}_{2}$. Furthermore, similar to the case of mortar, the amount of $\mathrm{CO}_{2}$ uptake by demolished concrete increased significantly when the test materials were alternately wetted and dried. However, the amount of $\mathrm{CO}_{2}$ uptake by demolished concrete was found to be smaller than that of the new mortar, especially when materials were subjected to alternately wetted and dried exposure condition. One of the reasons was thought to be the frequency of wetting, which was changed from twice (for mortar) to once (for concrete) a week. These experiments lead to the suggestion that the carbonation rate of demolished concrete is relatively-rapid under the actual environment.

\subsection{Results of field survey}

The results of the field survey and tests are listed in Table 5. The survey revealed that in almost all cases the primary crushing is carried out using a jaw crusher and secondary crushing is implemented by using an impact

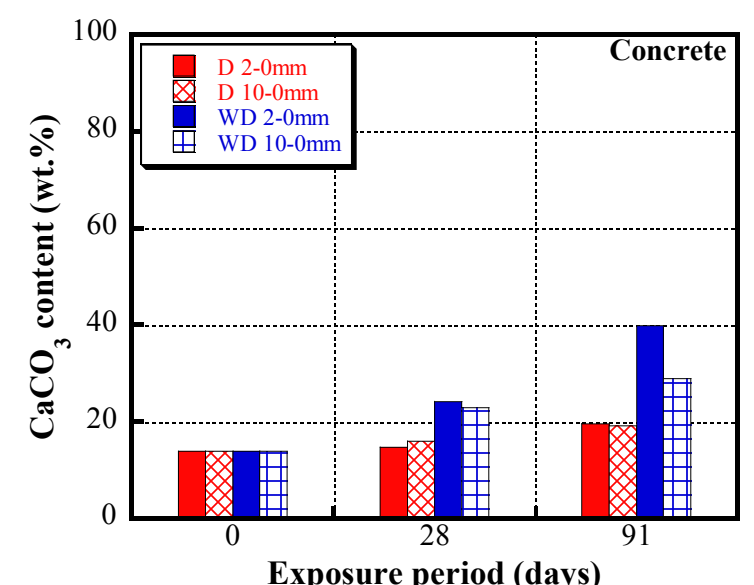

Fig. $7 \mathrm{CaCO}_{3}$ content in cement paste of demolished concrete. 
Table 4 Results of experiment on demolished concrete.

\begin{tabular}{|c|c|c|c|c|c|c|c|c|c|c|}
\hline \multirow{2}{*}{$\begin{array}{l}\text { Exposed } \\
\text { condition }\end{array}$} & \multirow{2}{*}{$\begin{array}{c}\text { Particle } \\
\text { sizes } \\
\text { mm }\end{array}$} & \multicolumn{3}{|c|}{0 days } & \multicolumn{3}{|c|}{28 days } & \multicolumn{3}{|c|}{91 days } \\
\hline & & $\begin{array}{c}\text { insol. } \\
\%\end{array}$ & $\begin{array}{c}\mathrm{Ca}(\mathrm{OH})_{2} \\
\%\end{array}$ & $\begin{array}{c}\mathrm{CaCO}_{3} \\
\%\end{array}$ & $\begin{array}{c}\text { insol. } \\
\%\end{array}$ & $\begin{array}{c}\mathrm{Ca}(\mathrm{OH})_{2} \\
\%\end{array}$ & $\begin{array}{c}\mathrm{CaCO}_{3} \\
\%\end{array}$ & $\begin{array}{c}\text { insol. } \\
\%\end{array}$ & $\begin{array}{c}\mathrm{Ca}(\mathrm{OH})_{2} \\
\%\end{array}$ & $\begin{array}{c}\mathrm{CaCO}_{3} \\
\%\end{array}$ \\
\hline \multirow{2}{*}{ D } & $2-0$ & \multirow{4}{*}{68.7} & \multirow{4}{*}{4.47} & \multirow{4}{*}{13.88} & 65.6 & 2.9 & 14.7 & 68.5 & 2.7 & 19.6 \\
\hline & $10-0$ & & & & 74.7 & 2.0 & 16.0 & 77.2 & 1.8 & 19.2 \\
\hline \multirow{2}{*}{ DW } & $2-0$ & & & & 67.3 & - & 24.1 & 68.4 & - & 39.9 \\
\hline & $10-0$ & & & & 66.2 & - & 22.9 & 68.5 & - & 29.0 \\
\hline
\end{tabular}

"-" means that the endothermic peak was indeterminable.

Table 5 Results of field survey and experiment on recycled crusher-run stone.

\begin{tabular}{|c|c|c|c|c|c|c|c|c|c|c|c|c|}
\hline \multirow{3}{*}{ Case } & \multicolumn{5}{|c|}{ Survey } & \multicolumn{7}{|c|}{ Experiment } \\
\hline & \multicolumn{2}{|c|}{ Crushing method } & \multicolumn{3}{|c|}{ Storage method } & \multicolumn{5}{|c|}{ Crushing method } & \multirow[b]{2}{*}{$\begin{array}{c}\text { insol. } \\
\%\end{array}$} & \multirow{2}{*}{$\begin{array}{c}\mathrm{CaCO}_{3} \\
\%\end{array}$} \\
\hline & Machine & $\begin{array}{l}\text { Capacity } \\
\text { ton/day }\end{array}$ & $\begin{array}{c}\text { Total } \\
\text { period }\end{array}$ & Material & Product & $\begin{array}{c}40 \mathrm{~mm} \\
\%\end{array}$ & $\begin{array}{c}20 \mathrm{~mm} \\
\%\end{array}$ & $\begin{array}{c}5 \mathrm{~mm} \\
\%\end{array}$ & $\underset{\%}{2 \mathrm{~mm}}$ & $\begin{array}{c}0.5 \mathrm{~mm} \\
\%\end{array}$ & & \\
\hline A & $\begin{array}{l}\text { Primary : Jaw } \\
\text { Secondary : Impact } \\
\text { Tertiary : Gyratory }\end{array}$ & 2000 & $\begin{array}{l}\text { within } \\
1 \text { month }\end{array}$ & outdoors & outdoors & 100 & 84 & 15 & 6 & 2 & 58 & 34.5 \\
\hline B & $\begin{array}{l}\text { Primary : Jaw } \\
\text { Secondary : Impact }\end{array}$ & 3000 & $\begin{array}{l}\text { within } \\
1 \text { month }\end{array}$ & outdoors & outdoors & 99 & 80 & 37 & 26 & 5 & 65 & 22.7 \\
\hline $\mathrm{C}$ & $\begin{array}{l}\text { Primary : Jaw } \\
\text { Secondary : Impact }\end{array}$ & 820 & $\begin{array}{l}\text { within } \\
1 \text { month }\end{array}$ & outdoors & $\begin{array}{l}\text { outdoors } \\
\text { with roof }\end{array}$ & 100 & 69 & 19 & 12 & 4 & 66 & 30.2 \\
\hline $\mathrm{D}$ & $\begin{array}{l}\text { Primary : Jaw } \\
\text { Secondary : Impact }\end{array}$ & 3520 & $\begin{array}{l}1 \text { to } 3 \\
\text { months }\end{array}$ & $\begin{array}{l}\text { outdoors } \\
\text { with roof }\end{array}$ & $\begin{array}{l}\text { outdoors } \\
\text { with roof }\end{array}$ & 100 & 79 & 30 & 20 & 6 & 57 & 24.4 \\
\hline $\mathrm{E}$ & $\begin{array}{l}\text { Primary : Jaw } \\
\text { Secondary : Impact }\end{array}$ & 2040 & $\begin{array}{l}1 \text { to } 3 \\
\text { months }\end{array}$ & outdoors & outdoors & 100 & 80 & 27 & 19 & 6 & 55 & 25.8 \\
\hline $\mathrm{F}$ & $\begin{array}{l}\text { Primary : Jaw } \\
\text { Secondary : Impact }\end{array}$ & 640 & $\begin{array}{l}1 \text { to } 3 \\
\text { months }\end{array}$ & outdoors & outdoors & 100 & 74 & 22 & 14 & 5 & 70 & 29.8 \\
\hline G & $\begin{array}{l}\text { Primary : Jaw } \\
\text { Secondary : Impact }\end{array}$ & 630 & $\begin{array}{l}\text { within } \\
1 \text { month }\end{array}$ & outdoors & outdoors & 96 & 61 & 25 & 17 & 4 & 63 & 18.8 \\
\hline $\mathrm{H}$ & $\begin{array}{l}\text { Primary : Jaw } \\
\text { Secondary : Impact }\end{array}$ & 480 & $\begin{array}{l}1 \text { to } 3 \\
\text { months }\end{array}$ & outdoors & outdoors & 100 & 73 & 18 & 9 & 5 & 68 & 34.3 \\
\hline Ave. & & & & & & 99 & 75 & 24 & 15 & 5 & 63 & 27.6 \\
\hline
\end{tabular}

crusher except in case A, in which tertiary crushing was carried out using a gyratory crusher. The crushing capacities of these crushers varied largely, from 480 to 3520 tons per day. Looking at the storage conditions, one can see that the material (demolished concrete) and product (recycled crusher-run stone) are fully exposed to the atmosphere in most cases. Therefore, it can be said that recycle concrete is generally in the alternately wetted and dried condition. Additionally, for half the cases, the period between the acceptance of materials and shipment of products is less than a month, while for the rest of the cases, this period ranges from one to three months.

The results of the tests are shown in Fig. 8. On aver- age, the ratio of particles with sizes up to 5 millimeters was about $24 \%$, as determined from the screening test. The ratio of the insoluble residue was found to be about $63 \%$ (determined by insoluble residue test) and the $\mathrm{CaCO}_{3}$ content was about $27.6 \%$, (determined by TG-DTA). It is assumed that the aggregate of demolished concretes in this survey was not limestone because the ratio of insoluble residue was not extremely small in any of these cases.

Inputting the results of these tests into equation (1), the amount of $\mathrm{CO}_{2}$ absorbed in one ton of demolished concrete was estimated to be 10.8 kilograms. However, the actual amount of $\mathrm{CO}_{2}$ absorbed is possibly greater than this value because the amount of $\mathrm{CO}_{2}$ absorbed by 
particles larger than 5 millimeters was not taken into account in the calculation. Moreover, the actual result includes not only the amount of $\mathrm{CO}_{2}$ absorbed during the recycling process but also the amount of $\mathrm{CO}_{2} \mathrm{ab}$ sorbed during the service life, maintenance work, and demolition of the reinforced concrete structure.

\subsection{Results of $\mathrm{LCCO}_{2}$ calculation}

The results of $\mathrm{LCCO}_{2}$ calculation with inclusion of $\mathrm{CO}_{2}$ uptake are shown in Fig. 9, and a comparison between the exclusion and inclusion of $\mathrm{CO}_{2}$ uptake in calculating $\mathrm{LCCO}_{2}$ is shown in Fig. 10. One can find that the amount of $\mathrm{CO}_{2}$ uptake is much lower than the amount of $\mathrm{CO}_{2}$ emission during the material process but it is higher than the amount of $\mathrm{CO}_{2}$ emission during the construction, demolition, recycling, and transport processes. Therefore, it can be said that the amount of $\mathrm{CO}_{2}$ uptake almost compensates for the amount of $\mathrm{CO}_{2}$ emission during the demolition and recycling processes. Moreover, the value of $\mathrm{LCCO}_{2}$ with consideration of $\mathrm{CO}_{2}$ uptake is about $5.5 \%$ lower than the case without consideration of $\mathrm{CO}_{2}$ uptake.

\section{Discussion}

Japan's concrete production in the year 2000 was approximately 500 million tons, accounting for $25 \%$ of Japan's total material input (Noguchi and Fujimoto 2007). On the other hand, Japan's waste totaled 458 million tons (general waste: 52 million tons; industrial waste: 406 million tons) in 2000, of which demolished concrete discharged from demolition sites accounted for 35 million tons (MLIT 2008, p.65-69). If 35 million tons of demolished concrete are discharged every year, the amount of $\mathrm{CO}_{2}$ uptake by the recycled crusher-run is approximately 0.37 million tons per year. Consequently, the contribution of the construction industry to net $\mathrm{CO}_{2}$ emissions might have been overestimated.

In this research, the following discussion with regards to the amount of cement used in concrete may give a more quantitative image of the $\mathrm{CO}_{2}$ uptake:

(a) To create 1000 kilograms of cement, about 1100 kilograms of the limestone is used (e.g. Taiheiyo Cement Co. 2010, p.42-43). If $100 \%$ of this limestone is $\mathrm{CaCO}_{3}$, about 480 kilograms of $\mathrm{CO}_{2}$ (calculated by the molecular weights of $\mathrm{CaCO}_{3}$ and $\mathrm{CO}_{2}$ ) are emitted when the $\mathrm{CaCO}_{3}$ in limestone is decomposed into $\mathrm{CaO}$ and $\mathrm{CO}_{2}$ at high temperature.

(b) The actual cement content in cement paste of hardened concrete was reported to be as high as $74 \%$ due to the loss of water in concrete due to bleeding, hydration, drying, etc (JICE 1997, p.57-60). If so, 1000 kilograms of initial cement in fresh concrete is apparently equivalent to 1350 kilograms of hardened cement paste.

(c) The results of experiments on demolished concrete and field surveys have proved that the $\mathrm{CaCO}_{3}$ content in hardened cement paste is about $30 \%$.

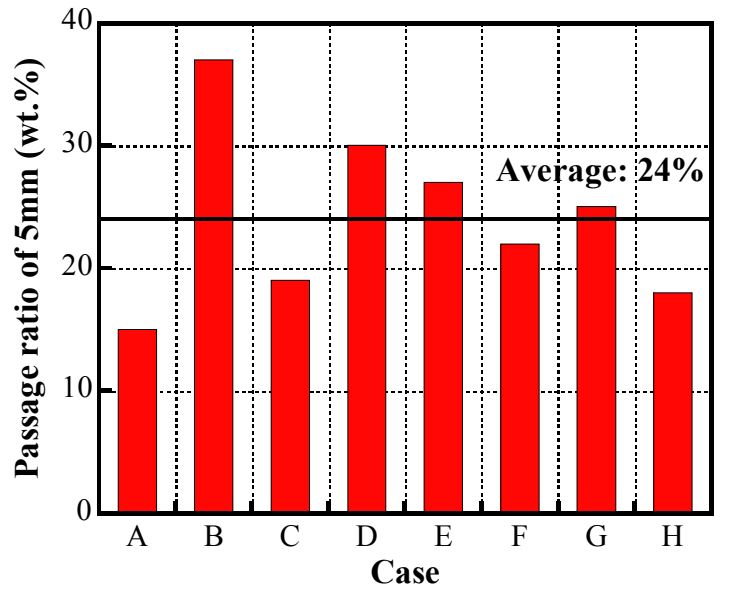

(a) Passage ratio of 5-mm particles.

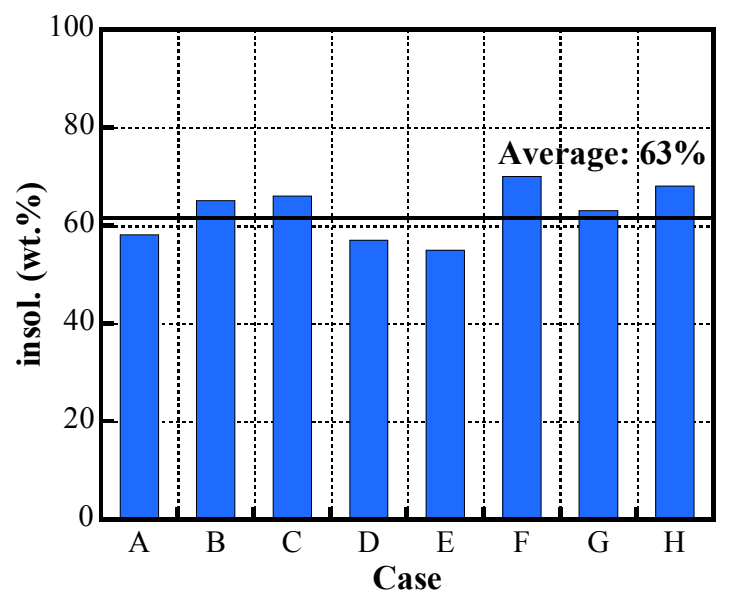

(b) Insoluble residue

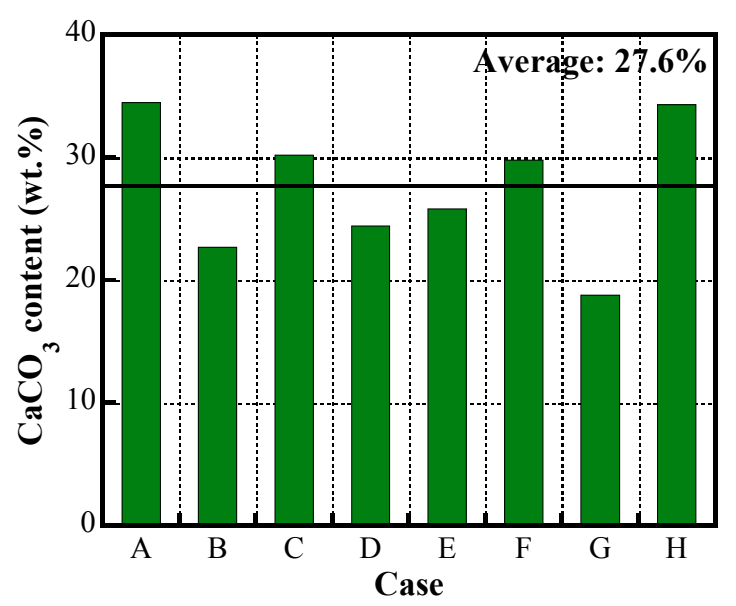

(c) $\mathrm{CaCO}_{3}$ content

Fig. 8 Results of experiment in recycled crusher-run.

From (a), (b) and (c), the $\mathrm{CaCO}_{3}$ content from 1000 kilograms of cement (or 1350 kilograms of hardened cement paste) can be estimated to be approximately 405 kilograms (30\% of 1350 kilograms), which means about 180 kilograms of the $\mathrm{CO}_{2}$ (calculated by the molecular 


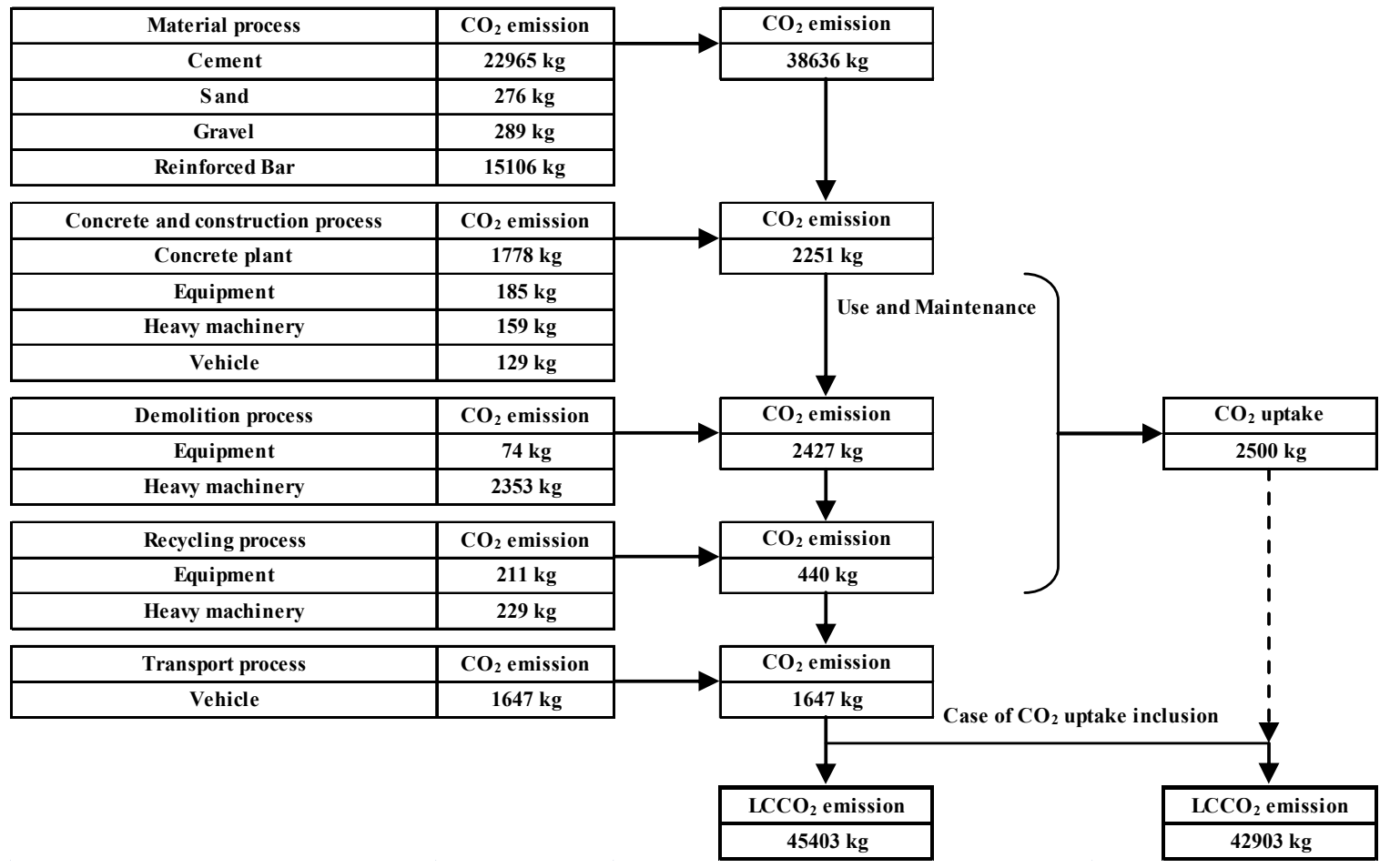

Fig. 9 Results of $\mathrm{LCCO}_{2}$ calculation with inclusion of $\mathrm{CO}_{2}$ uptake.

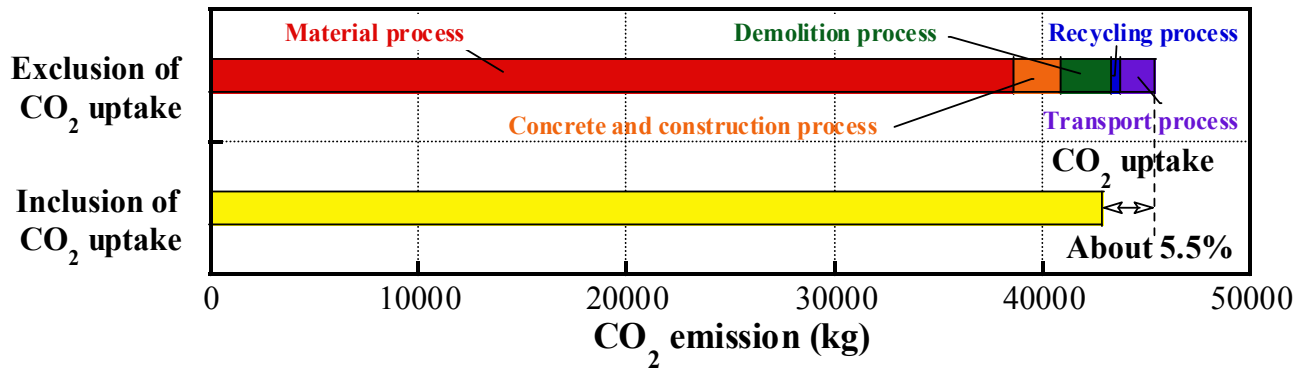

Fig. 10 Comparison between exclusion and inclusion of $\mathrm{CO}_{2}$ uptake in calculating $\mathrm{LCCO}_{2}$.

weights of $\mathrm{CaCO}_{3}$ and $\mathrm{CO}_{2}$ ) is absorbed during the demolition and recycling processes. In other words, the amount of $\mathrm{CO}_{2}$ uptake (180 kilograms) is nearly equivalent to $38 \%$ of the $\mathrm{CO}_{2}$ emitted from decomposition of raw limestone during cement production (480 kilograms).

\section{Conclusions}

At present, reducing $\mathrm{CO}_{2}$ emissions is an important issue to cope with global warming, and the construction industry is no exception since concrete is undoubtedly one of the most widely used construction materials. The following conclusions are drawn from this study:

(1) The amount of $\mathrm{CO}_{2}$ uptake increases significantly when the particle size is small and when crushed material is alternately wetted and dried.

(2) The investigation on the $\mathrm{CO}_{2}$ uptake of demolished concrete obtained from recycling plants gave rise to the quantification that the amount of $\mathrm{CO}_{2}$ uptake in one ton of recycled crusher-run ( 0 to 40 millimeters) is estimated to be approximately 11 kilograms. However, this result is based on a survey of a limited number of 8 recycling plants. Further surveys are necessary to improve the accuracy of this estimation.

(3) The $\mathrm{LCCO}_{2}$ calculation result when considering $\mathrm{CO}_{2}$ uptake during demolition and recycling was found to be approximately $5.5 \%$ less than when the $\mathrm{CO}_{2}$ uptake is not taken into account.

(4) When calculating the $\mathrm{LCCO}_{2}$, taking into account not only the $\mathrm{CO}_{2}$ uptake during demolition and recycling processes but also the $\mathrm{CO}_{2}$ uptake of the in-service period may lead to more accurate result. This matter should be further investigated in the future. 


\section{Acknowledgements}

The authors would like to express their sincerely gratefulness to Mr. Hiroshima at Waseda University (Shimizu Corporation) for his valuable support in the survey, and to Mr. Nomura at Waseda University (Sekisui House, Ltd.) for his substantial support in our experiments.

\section{References}

Engelsen, C. J., Mehus, J., Pade, C. and Sæther, D. H., (2005). "Carbon dioxide uptake in demolished and crushed Concrete." Nordic Innovation Centre project number 03018, Norwegian Building Research Institute.

JICE, (1997). "Development of recycling technology for recycled aggregate concrete." Tokyo: Japan Institute of Construction Engineering, Report for Fiscal 1996, 57-60. (in Japanese)

JSCE, (2004). “Assessment for environmental impact of concrete (Part 2)." Japan Society of Civil Engineers Concrete Engineering Series, 62, 32-40. (in Japanese)

Kuroda, Y. and Hashida, H., (2005). "A closed-loop concrete system on a construction site." In: V. M. Malhotra and K Sakai, Eds. Sustainable Development of Cement, Concrete and Concrete Structure, Proceedings of CANMET/ACI/JCI three-day international symposium, Toronto, Canada, 5-7 October 2005, 667-683.

Lagerblad, B., (2005). "Carbon dioxide uptake during concrete life cycle - State of the Art." Nordic Innovation Centre project number 03018, Swedish Cement and Concrete Research Institute.

MLIT, (2008). "White paper on land, infrastructure, transport and tourism in Japan 2008 [online]."
Ministry of Land, Infrastructure, Transport and Tourism, 65-69. Available from: < http://www.mlit.go. jp/common/000055283.pdf $>$ [Accessed 27 Dec 2010]

Naik, T. R. and Moriconi, G., (2005). "Environmental-friendly durable concrete made with recycled materials for sustainable concrete construction." In: V. M. Malhotra and K. Sakai, Eds. Sustainable development of cement, concrete and concrete structure, Proceedings of CANMET/ACI/JCI three-day international symposium, Toronto, Canada, 5-7 October 2005, 485-505.

Nakamura, H., (1994). "Study on the primary factors affecting on carbonation." Cement Science and Concrete Technology, 48, 584-589. (in Japanese)

Nielsen, C. V. and Glavind, M., (2007). "Danish experiences with a decade of green concrete." Journal of Advanced Concrete Technology, 5(1), 3-12.

Noguchi, T. and Fujimoto, S., (2007). "Evaluation and minimization of life cycle environmental risk of concrete structures." In: Y. M. Chun, P. Claisse, T. R. Naik and E. Ganjian, Eds. Sustainable construction materials and technologies, Proceedings of the international conference, Coventry, U.K., 11-13 June 2007. Leiden: Taylor and Francis/Balkema, 769-777.

Pommer, K. and Pade, C., (2005). "Guidelines - Uptake of carbon dioxide in the life cycle inventory of concrete." Nordic Innovation Centre project number 03018, Danish Technological Institute.

Taiheiyo Cement Co., (2010). "CSR report 2010 [online]." Tokyo: Taiheiyo Cement Corporation, 42-43. Available from: <http://www.taiheiyo-cement. co.jp/english/csr/pdf/2010/csr_english.pdf $>$ [Accessed 27 Dec 2010] 